\title{
Notas sobre pluralismo, diálogo inter-religioso e missão
}

\author{
Considerations on pluralism, \\ interreligious dialogue and mission
}

David Mesquiati de Oliveira

\section{Resumo}

Este artigo trata sobre a questão da missão cristã em um mundo plural. Assume o diálogo inter-religioso como um valor e não como uma ameaça. Está dividido em duas seções. Na primeira, reflete sobre o aumento da percepção da pluralidade em nosso tempo e sobre a consequente abertura do cristianismo para o diálogo - não sem reveses e ambiguidades. Na segunda parte, aprofunda a reflexão teológica sobre o diálogo inter-religioso e a missão, partindo do mais fundamental para a fé cristã: o evento Cristo. Aponta para a necessidade de saber ouvir o outro a partir do lugar em que ele se encontra e não a partir do que conhecemos de suas doutrinas, teologias e ritos. Dessa forma, amplia a dinâmica do encontro, pois valoriza o diálogo que também se dá na vida diária, permitindo outras formas de percepção do encontro com o diferente e da experiência com o sagrado.

Palavras-chave: Encontro. Escuta do outro. Diálogo Inter-religioso.

\section{Abstract}

This article is about the Christian mission in a pluralistic world. Takes interreligious dialogue as a value and not as a threat. It is divided into two sections. At first, reflects on the increasing perception of plurality in our time and the consequent opening of Christianity for dialogue, not without setbacks and ambiguities. The second part deepens the theological reflection on 
interreligious dialogue and mission, starting from the most fundamental to the Christian faith: the Christ event. It indicates the need to know hear the other from the place where he is not from what we know of his doctrine, theology or ritual. It is an invitation to walk together and grow in sacred experience.

Keywords: Encounter. Listen to the other. Interreligious Dialogue.

\section{Introdução}

É ainda hoje terreno instável posicionar-se sobre o valor das outras religiões nos vários segmentos do cristianismo (católico, protestante histórico, pentecostal, etc.). Mais sensível ainda é para os que trabalham com ministérios específicos na área pastoral de missão, pois estes lidam diretamente com pessoas adeptas de diferentes religiões. Os questionamentos surgem tanto interna como externamente. Alguns grupos percebem na pluralidade e na consequente abertura para o diálogo algo negativo, optando por defender uma única verdade, e esta, no cristianismo (e muitas vezes restrita ao segmento que o grupo pertence). Nesse caso, a preocupação que nortearia a ação seria de cunho doutrinal, isto é, partir do "conceito" para o "contexto". Por outro lado, há os que se perguntam como assumir uma postura positiva em relação às outras religiões e ainda assim seguir com programas de evangelização que têm como objetivo converter pessoas de outras religiões ao cristianismo. $\mathrm{O}$ que de fato vê-se como bom e válido na outra religião seria o que se parece com o cristianismo? A outra religião é boa e teria também a verdade, apesar de diferente do cristianismo? Esses são temas complexos que requerem avanços na reflexão e que não terão aqui tratativa final. As questões doutrinais são importantes e o respeito ao outro inegociável. É preciso diálogo tanto com os de dentro quanto com os de fora para transpor intolerâncias.

Outra questão importante que assumimos aqui é que o diálogo interreligioso não poderia partir dos dogmas nem das sistematizações, mas do encontro entre seres humanos. A razão seria simples: o dogma e a tradição foram sedimentados para balizar e conduzir o religioso para a vida. Sendo as religiões diretamente relacionadas às culturas, passam por transformações que demandam reformulações sobre a forma de entender e aplicar seus textos sagrados em cada momento cultural, bem como de manter a riqueza de suas tradições - não sem tensões. Um processo de diálogo afeta as partes envolvidas, internalizando mudanças que podem ser profundas. Assim, as 
sistematizações precisariam acompanhar as transformações culturais da sociedade, se quiserem continuar a serviço da humanidade e não da religião em si. Nesse sentido, a reflexão teológica no interior de cada religião é desafiada a olhar mais de perto o contexto no qual está inserida e perceber os adeptos das diferentes religiões como seres humanos, isto é, a ler adequadamente seu tempo e lugar. Um antídoto para as teologias generalistas que, ao fixarem-se em determinada época referencial ou privilegiarem determinadas perspectivas, produzem exclusão e marginação por meio de seus princípios universais e autoaplicáveis, seria o convite para caminhar com os povos em suas diferentes culturas e religiões, considerando a vivência e os casos concretos e as histórias de vida de cada povo e cultura. Vários esforços nesta direção têm surgido no mundo, seja por iniciativa das comunidades em sua partilha de vida com o outro, seja nos esforços institucionais para transpor obstáculos e divisões, seja na busca de novos pressupostos teológicos mais dialogais. Como academia, deveríamos valorizar estas iniciativas.

Este texto foi dividido em duas seções. Na primeira, busca refletir sobre o aumento da percepção da pluralidade em nosso tempo e sobre a consequente abertura do cristianismo para o diálogo, não sem reveses e ambiguidades. $\mathrm{Na}$ segunda seção, aprofunda na reflexão teológica sobre o diálogo inter-religioso e missão, partindo do mais fundamental para a fé cristã: o evento Cristo. Dessa forma, espera contribuir para o debate sobre esse tema tão importante na atualidade.

\section{Abertura dialogal para o reconhecimento da pluralidade religiosa}

Nesta primeira seção buscaremos apresentar dois grandes processos de abertura em curso na igreja ocidental, tanto em sua vertente católica como em sua vertente protestante, incluindo os pentecostais. No primeiro tópico faremos uma breve introdução sobre as mudanças no magistério da Igreja Católica. No segundo, as mudanças no campo protestante. Sabemos que o cristianismo não está composto por blocos uniformes, mas por força do espaço disponível e da necessidade de refletir panoramicamente, buscaremos os traços mais marcantes, tanto no catolicismo como no protestantismo. $\mathrm{O}$ último tópico lançará luz sobre o conceito de pluralidade, relacionando-o com as religiões e com a missão. 


\subsection{Abertura dialogal do magistério católico para com as outras religiões}

Aquele sentimento de superioridade que fortemente permeou o cristianismo até o século passado - tanto de recorte católico ${ }^{1}$, quanto protestante ${ }^{2}$-, estaria sendo substituído paulatinamente, por uma revalorização das demais religiões ou, ao menos, do reconhecimento da legitimidade das outras religiões. A Declaração Nostra Aetate, Sobre a Igreja e as religiões não cristãs teria sido resultado dessa nova mentalidade - solenemente votada e aprovada em 1965, por ocasião do Concílio Vaticano II (1962-1965) -, em que se evidenciou a perspectiva positiva em relação às outras religiões (NA2).

Essa declaração inicia e termina com a ideia de fraternidade universal oriunda da paternidade universal de Deus. Sendo filhos e filhas de um mesmo Pai deveriam tratar-se como irmãos e irmãs que comungam inquietações religiosas. Na parte final do documento, por exemplo, afirma: "Não podemos, porém, invocar Deus como Pai comum de todos, se nos recusamos a tratar como irmãos alguns homens, criados à Sua imagem." (NA 5). Aqui, avança da simples constatação da existência de outras religiões para defender sua coexistência pacífica em respeito e contra todo tipo de discriminação. Infelizmente, na prática, 50 anos depois, os posicionamentos teológicos não evoluíram como era de se esperar.

É inegável a contribuição do Concílio Vaticano II para a abertura da Igreja Católica na relação com as demais religiões no mundo. Não temos como abordar toda a riqueza do concílio em tão pouco espaço, mas faremos apenas algumas "considerações", como o título do texto indicou. Ele rediscutiu a maneira de crer e estar no mundo da Igreja Católica, uma mudança de eixo em relação ao Concílio de Trento (século XVI) e ao Vaticano I (século XIX). Uma marca inovadora teria sido justamente a perspectiva otimista em relação às outras religiões. Contudo, alguns documentos oficiais ainda guardam ressalvas, gerando ambiguidades. Como harmonizar o decreto Unitatis Redintegratio e a Encíclica Ecclesiam Suam de Paulo VI com a Lumen Gentium 16-17,

\footnotetext{
${ }^{1}$ Mario de França Miranda afirma que o católico nutria esse sentimento de superioridade com relação às outras denominações cristãs, e com relação aos cultos não cristãos (tratados como superstição). Cf. MIRANDA, M. F. Um homem perplexo. O cristão na atual sociedade. 3. ed. São Paulo: Loyola, 1996, p. 55s.

${ }^{2}$ Perceberem-se como caminhos únicos de salvação seria típico dos sistemas religiosos de recorte monoteísta. Dessa forma, tais posturas estariam muito presentes nas várias versões do cristianismo (católico, protestante histórico, pentecostal, ortodoxa, etc.), bem como nos islamismos e nos judaísmos, mas não só.
} 
Gaudium et Spes 22, Ad Gentes 3, 7, 93 e 11, e a Nostra Aetate? Naquelas, o diálogo parte da missão e do serviço, sempre em perspectiva cristocêntrica e da não equivalência das religiões. No Vaticano II, as relações com as outras religiões recebem reformulação ${ }^{3}$ a partir das Escrituras judaico-cristãs e da tradição. Parte-se da unidade original da espécie humana. Na década de 90 do mesmo século, Redemptoris Missio e Diálogo e Anúncio atualizaram o espírito do concílio. Mas utilizando a metáfora do pêndulo, o século XX terminou com a Dominus Iesus freando vários avanços pós-concílio, retomando o conservadorismo intraeclesial católico, presente também na encíclica de João Paulo II Ut unum sint, de 1995, que apresentava como objetivo do movimento ecumênico a unidade visível dos batizados (parágrafo 77) e que sustentava que, na perspectiva católica e na sua práxis, a comunhão plena da Igreja Católica inclui a comunhão das igrejas particulares com a Igreja de Roma (parágrafo 97). Para alguns protestantes, o texto é interpretado no sentido de que seria necessário um retorno. $\mathrm{O}$ tema seria retomado de forma positiva e mais aberta ${ }^{4}$ somente com o início do pontificado do Papa Francisco, em 2013.

J. B. Libanio levantou algumas questões que ainda estariam pendentes no período pós-conciliar nas áreas epistemológica, psicológica, cultural, religiosa e teológica:

No campo do diálogo inter-religioso, permanece vultosa distância. Um primeiro passo consiste em obviar os diferentes obstáculos. De natureza espistemológica, temos o problema da verdade religiosa e a práxis correspondente. Em nível psicológico, custa-nos aceitar a diferença. Intrometem-se o fanatismo, dogmatismo, rigorismo, fundamentalismo. Não faltam dificuldades culturais, por parte da cultura individualista atual, da carência de consciência crítica e histórica, da consideração abstrata da religião sem olhar as pessoas que a praticam, do etnocentrismo. Do lado religioso e teológico, a concepção de Deus, a não aceitação da liberdade religiosa, as diferentes teologias da graça, da salvação, da Igreja e da natureza institucional de cada religião. ${ }^{5}$

\footnotetext{
${ }^{3}$ Ver, por exemplo, BÜRKLE, Heinz. "Teologia das religiões". In: LACOSTE, Jean-Yves (Dir.). Dicionário crítico de teologia. São Paulo: Paulinas; Loyola, 2004, pp. 1514-1518.

${ }^{4}$ É notória a nova postura de favorecer o encontro no pontificado de Francisco. Ver, por exemplo, PAPA FRANCISCO. Comunicação a Serviço de uma autêntica cultura do encontro. São Paulo: Paulinas; Paulus, 2014; PAPA FRANCISCO. Evangelii Gaudium: Exortação apostólica do Sumo Pontífice. São Paulo: Loyola; Paulus, 2013.

${ }^{5}$ LIBANIO, J. B. "Questões pendentes do Concílio Vaticano II". In: BRIGHENTI, Agenor; ARROYO, Francisco Merlos (Orgs.). O Concílio Vaticano II: batalha perdida ou esperança renovada? São Paulo: Paulinas, 2015, pp. 329-351. Aqui, p. 344.
} 
Demanda-se agora um tempo de cura, de restauração e de reparação. Os avanços e retrocessos neste mundo pluralista e belicoso indicam que não se avançou como deveria na construção de um "clima de diálogo, de oração, de purificação da memória, de conversão individual e coletiva, de superação

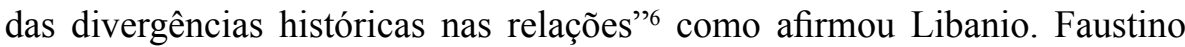
Teixeira, também enfatiza que, por mais que o Vaticano II e o período pósconciliar tenham significado um avanço na temática, de modo geral, ainda padece de uma visão teológica do acabamento em que as outras religiões seriam incompletas e expressões religiosas naturais, apenas uma preparação para o cristianismo. ${ }^{7}$ Com o Papa Francisco retomando os melhores impulsos do concílio, muitos vislumbram incentivos às aberturas históricas iniciadas, sem iludir-se, pois são muitas as barreiras a serem transpostas. O bispo de Roma acentuou a necessidade de diálogo e de uma cultura do encontro, mostrando com atitudes a nova disposição dialogal. ${ }^{8}$

\subsection{Abertura dialogal no mundo protestante histórico e pentecostal}

No segmento protestante identifica-se claramente um setor mais dialogal, conhecidos por sua luta por unidade visível das igrejas em todo o mundo, e outro mais fechado, seja por questões étnicas ou missionárias. Este último setor é bem numeroso, formado por igrejas engajadas em projetos evangelísticos de cunho conversionista, dentre os quais estariam os pentecostais, e por igrejas voltadas para imigrantes ou para os indígenas, etc. Já o primeiro setor, os ecumênicos, seria formado por aquelas igrejas que buscariam a unidade visível das igrejas, podendo ou não estar ligados ao Conselho Mundial de Igrejas (CMI), importante instância ecumênica global. As três principais dimensões de atuação do CMI compreendem a unidade entre os cristãos, a luta por justiça e o diálogo com outras religiões. ${ }^{9}$ A partir de estimativas globais, Hubert van Beek aponta que $50 \%$ dos cristãos no mundo seriam católicos. Os outros $50 \%$ estariam divididos meio a meio entre o movimento pentecostal-carismático e

\footnotetext{
${ }^{6}$ LIBANIO, "Questões pendentes do Concílio Vaticano II", p. 344.

7 TEIXEIRA, Faustino. "Caminhos do diálogo inter-religioso a partir do Vaticano II". In: BRIGHENTI, Agenor; ARROYO, Francisco Merlos (Orgs.). O Concílio Vaticano II: batalha perdida ou esperança renovada? São Paulo: Paulinas, 2015, pp. 244-261. Aqui, p. 248.

${ }^{8}$ Ver, por exemplo, PAPA FRANCISCO. Palavras do Papa Francisco no Brasil. São Paulo: Paulinas, 2013.

${ }^{9}$ SANTOS, Lyndon de Araújo. "Diálogo inter-religioso". In: BORTOLLETO FILHO, Fernando (Org.). Dicionário brasileiro de teologia. São Paulo: ASTE, 2008.
} 
as igrejas membros do CMI. Estas igrejas membros juntas somariam cerca de 560 milhões de adeptos. ${ }^{10}$

Em 1998, na celebração dos 50 anos do CMI percebeu-se a relativa baixa representatividade dos cristãos, pois nem todos os protestantes fazem parte do CMI; assim também a Igreja Católica não é membro do CMI nem tem manifestado intenção de tornar-se membro do CMI. Na sua relação com o CMI, a Igreja Católica participa de um grupo misto de trabalho. Foi por ocasião do jubileu que o CMI decidiu realizar um fórum, menos institucionalizado e mais aberto, para ver se com esta estratégia poderiam avançar na busca pela unidade cristã e do diálogo com outras religiões. Afirma van Beek:

Uma primeira consulta, organizada pelo CMI, teve lugar em 1998 e elaborou a proposta de convocar um Fórum, em nível mundial, com líderes das igrejas-membros do CMI (protestantes, anglicanas e ortodoxas), e de igrejas não membros do CMI (a Igreja Católica e as igrejas evangélicas, pentecostais, independentes, etc.). Isto é, a consulta concebeu o Fórum como um acontecimento único, com a tarefa de promover a unidade cristã para além das limitações estruturais do CMI. Um pequeno Comitê de Continuação foi constituído. ${ }^{11}$

Contudo, a reunião não contou com participação significativa, o que fez com que seus propugnadores insistissem com uma nova convocatória para o ano 2000, nos Estados Unidos da América, dessa vez consultando diferentes lideranças cristãs e propondo essa instância dialogal, que se diferenciava, sobretudo, pela nova metodologia mais aberta e menos institucional. A acolhida teria sido mais estimulante e organizaram um grande encontro no ano de 2002 no mesmo local, em que se fez representar diferentes líderes dos mais variados grupos cristãos (católicos, ortodoxos, protestantes históricos, pentecostais, igrejas independentes, etc.) e de várias partes do mundo. Ali concebeu-se o fórum como um processo, e nos últimos anos, tem dado mostras de um caminho viável. Nascia ali o Fórum Cristão Mundial. ${ }^{12}$

Este fórum já organizou diversos encontros regionais e dois grandes encontros mundiais nesse período. O terceiro encontro mundial está por

\footnotetext{
${ }^{10}$ BEEK, Hubert van. "O Fórum Cristão Mundial e a busca pela unidade cristã". In: OLIVEIRA, David Mesquiati (Org.). Pentecostalismos e unidade. São Paulo: Fonte Editorial; FPLC, 2015, pp. 13-26. Aqui, p. 15.

${ }^{11}$ BEEK, “O Fórum Cristão Mundial...”, p. 15.

${ }^{12}$ BEEK, “O Fórum Cristão Mundial...”, p. 16.
} 
celebrar-se na América Latina por volta do ano 2018. Como fruto dessa iniciativa promissora, surgiram outras instâncias de diálogo. $\mathrm{Na}$ América Latina, e diretamente incentivada pelo FCM, surgiu o Fórum Pentecostal Latino-americano e Caribenho (FPLC) em 2010, em um encontro em San José, Costa Rica. Em 2011, o FPLC esteve reunido em Lima, Peru, onde planejou uma série de encontros sub-regionais que se concretizaram ao longo do continente. Em 2012 no Chile, em 2013 na Colômbia, em 2014 no México e em 2015 no Brasil. O grupo tem procurado publicar os documentos dos encontros para dialogar com novos parceiros. ${ }^{13}$ Esse esforço de reunir os pentecostais e partilhar a mesa ainda não recebeu apoio massivo, mas é um claro sinal desse novo tempo de maior percepção da pluralidade e da necessidade de aprender a caminhar juntos.

Há também outras agremiações que contribuem para a unidade cristã no continente, como o Conselho Latino-americano de Igrejas (CLAI) ${ }^{14}$ e o Conselho Nacional de Igrejas Cristãs do Brasil (CONIC, do qual a Igreja Católica participa, e talvez, por esse motivo, muitas igrejas protestantes e pentecostais não queiram se afiliar, em uma clara demonstração de sentimento antiecumênico vigente). Cada iniciativa dessa conta com uma limitada adesão de representantes das diferentes igrejas, mas que em seu conjunto, representam uma significativa parcela das igrejas latino-americanas. Esses grupos trabalhariam a partir do cristianismo, mas mantendo comissões de estudo e reflexão para o diálogo inter-religioso.

A falta de recursos do exterior para financiar programas e projetos ecumênicos na América Latina aliada às crises econômicas e sociais da região, pode funcionar como um catalizador na percepção da necessidade de cooperação para sobreviver e para construir o Bem Comum no continente. É possível que no médio prazo esses movimentos e organizações coordenem

\footnotetext{
${ }^{13}$ Publicações: CAMPOS, Bernardo; ORELLANA, Luis (Eds.). Ecumenismo del Espíritu: pentecostalismo, unidad y misión. Lima: FPLC, FCM, 2012; CAMPOS, B.; ORELLANA, L. (Eds.). Fuego que une: pentecostalismo y unidad de la iglesia. Lima: FPLC; FCM, 2014; CAMPOS, B.; ORELlANA, L. (Eds.). Pentecostalismo y unidad en Centro América. Lima: FPLC; FCM, 2015; OLIVEIRA, David Mesquiati (Org.). Pentecostalismos e unidade: desafios institucionais, teológicos e sociais. São Paulo: Fonte Editorial; FPLC, FCM, 2015; VILHENA, Valéria Cristina (Org.). Evangélicas, por sua voz e participação: gênero em discussão. São Paulo: Fonte Editorial; FPLC, 2015.

${ }^{14}$ Ver, por exemplo, LONGUINI NETO, Luiz. O novo rosto da missão: Os movimentos ecumênicos e evangelical no protestantismo latino-americano. Viçosa: Ultimato, 2002; e, BATISTA, Israel (Org.). Desafios missionários da cooperação: diálogo entre as Igrejas da Europa e da América Latina. São Leopoldo: Sinodal; Quito: CLAI, 2007.
} 
suas ações de forma mais conjunta, reconhecendo a expertise de cada um em seu segmento e promovendo sinergia em torno da pastoral e do diálogo ecumênico e inter-religioso. Esse diálogo é urgente e é um grande desafio para as igrejas, mas não é uma novidade histórica, como alguns apregoam no sentido de ser uma marca do nosso tempo. Esse é o tema do próximo tópico.

\subsection{Pluralidade: não é uma novidade na história}

A pluralidade religiosa sempre existiu, mas não era "percebida" ou aceita como categoria. Nesse sentido, José Maria Vigil afirmou: "pela primeira vez grande parte da humanidade vive num ambiente religioso realmente plural"15. E continua:

A humanidade, nessas mais de oitocentas gerações humanas que dizem ter pisado este planeta, tem vivido sempre convencida de que a realidade era de uma forma determinada, a forma descrita por sua cultura e religião. No decurso da presente geração a humanidade está passando a conviver com a presença próxima e permanente de todas as religiões e culturas chamadas "universais", obrigadas a conviver competindo uma com as outras na apresentação de suas ofertas de sentido. ${ }^{16}$

Essa novidade está relacionada ao desenvolvimento tecnológico, que conectou o mundo. As Tecnologias da Informação e da Comunicação (TICs) de âmbito mundial, criaram a possibilidade de um encontro ininterrupto e em vias de alcance mundial, que possibilita a criação de "um fórum para o encontro mundial da diversidade religiosa. Já não podemos evitar o encontro inter-religioso"17. Além disso, nessa atual fase, os grupos e os indivíduos estão se empoderando, marcando posição, exigindo respeito e reparação. Nesse processo de empoderamento, tornam-se sujeitos de transformação. Com isso, o reconhecimento da pluralidade passa a ser uma exigência. Etnias, culturas, religiões, tribos urbanas, todos, buscam seu lugar na sociedade. Grupos que antes eram nomeados nos manuais teológicos como "seitas e heresias" não aceitam mais essas classificações unilaterais. Querem ser parceiros no diálogo,

\footnotetext{
${ }^{15}$ VIGIL, José Maria. Teologia do pluralismo religioso: para uma releitura pluralista do cristianismo. São Paulo: Paulus, 2006, p. 29.

${ }^{16}$ VIGIL, Teologia do pluralismo religioso, p. 31.

${ }^{17}$ SCHWÖBEL, Christoph. "Encontro inter-religioso e experiência fragmentária de Deus". Concilium 289 (2001), pp. 111-125. Aqui, p. 114.
} 
querem ser reconhecidos como outro, como alguém diferente, recebendo tratamento digno e correspondente aos demais seres humanos. José Maria Vigil exorta: "As religiões não são teorias: são pessoas crentes, pessoas de carne e osso. E podemos ver o influxo e a transformação que a religião faz em suas vidas, até mesmo sua santidade. Isso nos dá um conhecimento vivencial dessas religiões, muito mais influente que o conhecimento teórico, dado pelos livros, sobre suas doutrinas ou teologias". ${ }^{18}$ Assim, não basta a abertura para o encontro a partir da constatação da pluralidade. A atitude frente a este encontro é igualmente importante.

No encontro ecumênico com o diferente/outro todas as partes envolvidas no diálogo inter-religioso são desafiadas a se reconhecerem, aceitarem, e afirmarem suas diferenças religiosas enquanto tais, sempre como manifestações de diferentes práticas e compreensão de suas relações com o sagrado, repelindo toda tentativa de se querer reduzir o outro diferente à semelhança de si mesmo. ${ }^{19}$

São notórias as mudanças no contexto religioso da América Latina, de mais aceitação, tolerância e convivência com diferentes religiões, sem com isso negar que a intolerância religiosa ainda persiste em diferentes modos. José Maria Vigil afirmou:

O ecumenismo está em marcha, vivo, atuando dia e noite, constantemente, implícita e explicitamente, não somente onde é favorecido pelo nome, como também nos lugares onde não é reconhecido, ou onde se crê estar-se salvo dele. Está em marcha e não há quem possa detê-lo. O mundo se unifica, inter-relaciona-se, dialoga, conhece, percebe, experimenta, informa-se, intercambia... e as religiões se aproximam, intuem, adivinham, pressentem, dialogam e convergem entre si. E, como sempre, Deus não está alheio a sua obra. ${ }^{20}$

Vigil empregou o termo "ecumenismo" em seu sentido etimológico original e não reduzido ao diálogo entre cristãos. Ele percebeu que esse movimento é irreversível, e as religiões irão dialogar cada vez mais (formal e

\footnotetext{
${ }_{18}$ VIGIL, Teologia do pluralismo religioso, p. 30.

${ }^{19}$ MATTOS, P. A. "Para uma teologia ecumênica das religiões no Brasil”. Tempo e Presença 25, n. 332 (2003), pp. 12-15. Aqui, p. 15.

${ }^{20}$ VIGIL, Teologia do pluralismo religioso, pp. 285-286.
} 
informalmente). Torres Queiruga, na mesma linha, afirma estar acontecendo um "ecumenismo real":

Se se olham os processos reais, compreende-se sem grande dificuldade que, no movimento profundo da história, está acontecendo já um ecumenismo real de alcance incalculável. Hoje praticamente todas as religiões já entraram em mútuo contato; e é claro que isso não acontece sem profundas modificações. As instituições cristãs estão real e verdadeiramente presentes nas outras religiões, da mesma forma que as instituições destas estão presentes no cristianismo. Seria concebível o estado atual do cristianismo sem seu contato com o hinduísmo e o budismo, ou sem sua secular convivência com o Islã? É possível pensar - recorde-se Gandhi - que a sacralização das castas não foi profundamente erosionada pela afirmação cristã da igualdade de todos perante Deus? Pode alguém imaginar que - apesar das atuais restrições - a leitura do Alcorão seguirá com seu literalismo fundamentalista depois que os teólogos islâmicos começaram a entrar em contato com a crítica cristã da Bíblia? [...] de fato está acontecendo uma expansão real das valências universalistas presentes em cada revelação concreta. ${ }^{21}$

Há muito ainda por caminhar. Conhecemos pouco sobre as religiões do mundo. Sobre as religiões indígenas, por exemplo, mantemos muitas generalizações. Que novas pontes para o diálogo possam ser construídas, e que seja possível maior proximidade e acompanhamento entre os povos. Como afirmou Raimond Panikkar: "O diálogo religioso deve ser genuinamente religioso, e não simplesmente uma troca de doutrinas e pontos de vista intelectuais [...] O diálogo deve surgir da profundidade de meu parceiro"22.

No dizer de Leonard Swidler, "experimentar 'de dentro' a religião ou ideologia de outro é possível a todos" $"$. No diálogo, buscamos experimentar a religião do outro a partir "de dentro", do mais profundo, do espiritual. Esse pertencer múltiplo permite ao cristão captar e entender as verdades do outro nas categorias próprias daquela cultura e fé $\mathrm{e}^{24}$.

${ }^{21}$ TORRES QUEIRUGA, A. “El diálogo de las religiones en el mundo actual”. In: GOMIS, J. (Org.). El Vaticano III. Cómo lo imaginan 17 cristianos. Barcelona: Herder; El Ciervo, 2001, pp. 67-84.

${ }^{22}$ PANIKKAR, R. The Intrareligious Dialogue. New York: Paulist, 1978, p. 50.

${ }^{23}$ SWIDLER, L. Cristãos e não-cristãos em diálogo. São Paulo: Paulinas, 1988, p. 92.

${ }^{24}$ Ver também, Michael Amaladoss, que propõe um desafio mútuo e cooperação conjunta das religiões, superando a simples partilha de experiências e opiniões. Cf. AMALADOSS, M. Pela estrada da vida: prática do diálogo inter-religioso. São Paulo: Paulinas, 1995. 
Agora, voltando à questão pastoral da missão, o pluralismo religioso apresenta desafios, exigências e questionamentos. Quando a discussão teológica toca temas caros ao cristianismo, como essa postura de abertura se manifesta? Por exemplo, se o cristianismo advoga uma única economia salvífica, qual seria a legitimidade das outras religiões? A segunda seção desse ensaio refletirá sobre isso.

\section{As religiões e a economia salvífica cristã}

$\mathrm{Na}$ perspectiva cristã há uma única economia salvífica. As demais religiões participam dessa economia contribuindo com as "sementes do Verbo" e com novas matrizes culturais que permitam expressar certos elementos da fé que não puderam ser expressos na tradição cristã. Afirma França Miranda: "esses novos horizontes e essas novas expressões religiosas não são, a priori, neutras ou hostis à fé cristã, pois estão também prenhes dos elementos crísticos". E prossegue França, considerando as religiões em seus horizontes respectivos, "oferece outros horizontes para olhar a si próprio, capacitando-o [o cristianismo] a reinterpretar a verdade que é Jesus Cristo com outras linguagens e estruturas mentais" ${ }^{25}$. Esse seria o sentido das religiões no plano de salvação de Deus. Não completam o que faltou em Cristo, mas o que falta em nossa apropriação ${ }^{26}$ dessa revelação de Deus.

Como também a fé cristã só se encontra já concretamente contextualizada, pode se dar que, no diálogo com outra religião, o que parece fazer dificuldade à fé, de fato, apenas está se opondo à versão cultural que a expressa. Não podemos também excluir que certas características da ação salvífica de Deus tenham encontrado maior dificuldade de vivência e de expressão na cultura semita ou helenista, que nos são familiares. Nesse caso, outras culturas poderiam conter elementos mais afins à atuação divina, constituindo-se como mediações legítimas dessa mesma atuação. ${ }^{27}$

Hans Urs von Balthasar, em posicionamento semelhante, ensina que Cristo integra e cumpre o que há de verdadeiro e de bom em todas as religiões e filosofias da humanidade, inclusive em seu judaísmo de origem. Em João

\footnotetext{
${ }^{25}$ MIRANDA, M. F. A igreja numa sociedade fragmentada. São Paulo: Loyola, 2006, p. 294. ${ }^{26}$ Ver, por exemplo, MIRANDA, M. F. “As religiões na única economia salvífica”. Atualidade Teológica 10 (2012), pp. 9-26. Aqui, p. 26.

${ }^{27}$ MIRANDA, A igreja numa sociedade fragmentada, p. 291.
} 
19.28, as Escrituras registram: "Mais tarde, sabendo então que tudo estava concluído, para que a Escritura se cumprisse, Jesus disse: 'Tenho sede"'. Assim, Cristo une

o que não poderia ser unido em "tempos passados": o Sumo Sacerdote e o Cordeiro imolado, o Rei e o Servo, o Templo e o adorador dentro do Templo, o sagrado e o profano e, por fim, sua origem em Deus e seu nascimento feito homem. E ele o faz, no fim de tudo, sem que para isso tenha que quebrar as antigas tábuas da Lei, mas "[cumprindo] a Escritura". ${ }^{28}$

Dessa forma, nosso desafio é conhecer, captar e compreender as diferentes expressões religiosas em seus respectivos horizontes culturais. Para isso será necessário um verdadeiro encontro com o outro, com sua cultura, assumindo-a. As verdades daí resultantes deverão ser confrontadas com as verdades da fé cristã. O resultado do encontro não deve ser uma síntese acrítica e aglutinadora. Dois resultados e diferentes consequências são esperados. Primeiro, a autocompreensão cristã sairá do encontro enriquecida com a perspectiva e verdade do outro; os conteúdos da tradição serão purificados e aperfeiçoados; e o cristianismo experimentará maior capacidade de universalização. $\mathrm{O}$ segundo resultado esperado é que nem todos os elementos não cristãos serão integrados no confronto. As contradições com as verdades e valores evangélicos não poderão ser assumidas pelo cristianismo sob o risco de afetar negativamente a identidade cristã. ${ }^{29}$ Balthasar entende que temos que estar familiarizados com as religiões do mundo e também ser capazes de discutir tanto sua verdade quanto aquilo em que diferem da revelação cristã. ${ }^{30}$

Por outro lado, não queremos cair em uma noção de monopólio da salvação concentrado na religião - seja no cristianismo, seja estendendo às demais religiões. A salvação não tem a ver com filiação religiosa. Do ponto de vista cristão, o critério fundamental para avaliar as práticas humanas em busca de salvação teria sido revelado em Jesus Cristo: "consiste na prática do amor a Deus e ao próprio semelhante, e não na participação em cultos de outras religiões" ${ }^{31}$. A pessoa e obra de Jesus são centrais e normativas, como exemplo de amor ao próximo, de amor fraterno em consonância com o amor do Pai.

\footnotetext{
${ }^{28}$ BALTHASAR, H. U. Epilogue. San Francisco: Ignatius, 1995, p. 94.

${ }^{29}$ MIRANDA, A igreja numa sociedade fragmentada, p. 294 e 295.

${ }^{30}$ BALTHASAR, Epilogue, p. 16, 72.

${ }^{31}$ Cf. MIRANDA, M. F. O cristianismo em face das religiões. São Paulo: Loyola, 1998, p. 18.
} 
No que tange às religiões, aqui emerge a importância do diálogo interreligioso: possibilitar a comunhão interpessoal entre todos e todas, incluindo adeptos de outras religiões. "Somente a experiência do encontro pode problematizar e consequentemente ultrapassar os limites de determinado horizonte, sempre que não puder ser por ele totalmente equacionada e explicada" ${ }^{32}$. O encontro com o outro ou a atitude de abertura ao encontro convida ao diálogo e ao respeito mútuo, uma das características da atitude salvífica (amor fraternal) ${ }^{33}$. A Igreja cristã é desafiada a entrar em comunhão com as diversas formas de cultura, trazendo, assim, contribuições tanto para a cultura como para a Igreja (Gaudium et Spes, 44, 53, 58). Mas precisamos considerar que "não há como manter uma autêntica sensibilidade dialogal e uma honrada abertura ao outro com perspectivas teológicas acanhadas e inibidoras, que não conseguem visualizar a alteridade senão enquadrando-a em seu horizonte particular." ${ }^{34}$

\subsection{A missão e o pluralismo religioso}

Seria a missão realmente necessária nessa nova realidade de pluralismo, fragmentação e individualismo? David Bosch questiona-se a partir da perspectiva dos missionários que são enviados para outras culturas:

E no contexto da atual atitude de diálogo com adeptos de outros credos, cresce o número de missionários que se indaga se ainda faz sentido ir até os confins da terra por causa do evangelho cristão. Por que, realmente, alguém deveria "sofrer as angústias do exílio e as picadas de mosquitos" se as pessoas serão salvas de qualquer maneira? Afinal de contas, já é "suficientemente ruim ter um trabalho árduo a realizar, mas muito pior quando é discutível se esse trabalho vale a pena ser feito". ${ }^{35}$

\footnotetext{
${ }^{32}$ MIRANDA, $O$ cristianismo em face das religiões, p. 31 e 32.

${ }^{33}$ Ver, por exemplo, MIRANDA, “As religiões na única economia salvífica”, p. 21: “A própria teologia cristã, confirmada por pronunciamentos do magistério, já reconhece não só a salvação de Jesus Cristo acontecendo fora do âmbito cristão, mas ainda valoriza as demais tradições religiosas como mediações e contextos nos quais o ser humano responde à interpelação salvífica divina".

${ }^{34}$ TEIXEIRA, F. Indagações em torno da teologia do pluralismo religioso. Post scriptum (reflexões de 2005), 2012, pp. 1-4. Disponível em: <http://servicioskoinonia.org/relat/357.htm>. Acesso em 11 de fevereiro de 2015. Aqui, p. 1.

${ }^{35} \mathrm{BOSCH}$, D. J. Missão transformadora: mudanças de paradigma da teologia da missão. 2. ed. São Leopoldo: Sinodal, 2007, p. 437.
} 
Ser missionário do tipo "exilado", como indica Bosch, acrescenta às dificuldades da empreitada a falta de certeza e segurança com relação à real necessidade da atividade missionária no mundo atual. A resposta a essa questão passa pela posição teológica adotada sobre o diálogo inter-religioso. São várias as classificações sugeridas, e, por razões de espaço, ficaremos com a tripartite ${ }^{36}$ particularismo, inclusivismo e pluralismo - muito difundida na literatura -, combinada com uma segunda, que se apresenta como paralela: eclesiocentrismo, cristocentrismo e teocentrismo. ${ }^{37}$

A partir de um olhar crítico, as três opções têm o seu lado negativo: o particularismo seria da ordem da imposição, negando qualquer verdade do outro; o inclusivismo seria seletivo, pois reconhece apenas algumas verdades no outro, a partir de critérios próprios (Jesus); e o pluralismo, que parece ser o que mais leva em consideração o outro, no fundo seria indiferente, pois não teria critérios para as (in)verdades de cada religião $0^{38}$. Contudo, na falta de uma classificação mais apropriada, manteremos essa, cientes da sua limitação ${ }^{39}$.

No modelo particularista ou exclusivista a missão é entendida como tarefa para impedir a condenação dos não cristãos, e qualquer possibilidade de salvação sem a pregação explícita do evangelho e o conhecimento nominal de Jesus Cristo seria considerada falsa. A razão primária para uma pessoa estar "perdida" (sem salvação) é não ter tido a oportunidade de ouvir as Boas Novas sobre Jesus nesta vida ${ }^{40}$. O reducionismo é tão acentuado que exclusivistas disputarão espaço mesmo entre seus pares, uma vez que um determinado grupo cristão põe como meta "converter" inclusive outros grupos cristãos que não partilham de sua especificidade doutrinária. Aqui a atitude antiecumênica é justificada pela "obediência missionária". No contexto da América Latina

${ }^{36}$ Consideramos equivalentes as posições conhecidas como exclusivismo, restritivismo ou particularismo.

${ }^{37}$ COMISSÃO TEOLÓGICA INTERNACIONAL. O cristianismo e as religiões. São Paulo: Loyola, 1997, p. 13s. (n. 8-12). Para mais classificações, ver, por exemplo, VIGIL, Teologia do pluralismo religioso, p. 59s.

${ }^{38}$ SASS, W. "O Deus trinitário está presente antes da chegada do missionário". Estudos Teológicos 2 (2004), pp. 73-81. Aqui, p. 73s.

${ }^{39}$ Alan Race teria sido o grande divulgador da tipologia exclusivismo, inclusivismo e pluralismo. Veja, por exemplo, RACE, Alan. Christians and Religious Pluralism: Patterns in the Christian Theology of Religious. Londres: SCM, 1983. Gavin D'Acosta afirma que Radhakrishnan teria utilizado esta tipologia ao menos sessenta anos antes de Race. Cf. D'ACOSTA, Gavin. La trinidad y el diálogo interreligioso. Salamanca: Secretaria Trinitario, 2006, p. 81s.

${ }^{40}$ Ver, por exemplo, SANDERS, J. (Ed.). E aqueles que nunca ouviram? Três pontos de vista sobre o destino dos não-evangelizados. Arapongas: Aleluia, 1999. 
de maioria católica alguns grupos protestantes e ou pentecostais assumem a postura de "não posso reconhecer o outro como cristão porque isso significaria não ter a quem evangelizar". E isso seria o fim de algumas dessas igrejas, que veem na cristianização do mundo (lê-se, "vigorar minha versão da fé cristã") o objetivo principal. ${ }^{41}$ Esta postura julga os demais seres humanos a partir da pertença a um tipo de igreja cristã e, com isso, poderia ser também chamada eclesiocêntrica.

O modelo pluralista, por sua vez, considera todas as religiões outros caminhos para a salvação. Essa "indiferença" para com o outro substituiria o chamado à conversão por uma aceitação que poderíamos chamar "acrítica". Assim, a conversão deixa de ser o objetivo primário da missão. Se há um anúncio de cada religião, ele deveria ser normativo apenas internamente. Dessa forma, o Evangelho de Jesus ajudaria o cristão a ser um melhor cristão, e os ensinos de Buda ajudariam o budista a ser um melhor budista, e assim sucessivamente. Isso não excluiria o anúncio universal de cada religião, mas teria um valor informativo, buscando completude nos múltiplos rostos de Deus, como podemos deduzir de Paul Knitter:

Os cristãos devem dar testemunho de Cristo para a promoção do Reino. Todos os povos, todas as religiões devem conhecê-lo, para atingir o conteúdo pleno da presença de Deus na história. E aí estão, o propósito e a motivação de ir até os confins da terra. Mas na nova eclesiologia e no novo modelo da verdade, admite-se que todos os povos deveriam conhecer algo sobre Buda, sobre Maomé. Isso faz parte também do objetivo e da inspiração do trabalho missionário: dar testemunho, para que os cristãos possam aprofundar e expandir seu próprio conceito da presença e do propósito de Deus no mundo. Com esse mútuo testemunhar, esse mútuo crescimento, o trabalho da promoção do Reino avança. ${ }^{42}$

Mas essa "nova eclesiologia" e esse "novo modelo de verdade" não foram assumidos amplamente. Essa perspectiva seria um paralelo ao chamado

${ }^{41}$ Em uma mesa de encontro no Chile ouvimos um líder de uma denominação pentecostal explicitar, literalmente, essa preocupação. Cf. OLIVEIRA, David Mesquiati. "Os pentecostais e a mesa de debate: o caso do Fórum Pentecostal Latino-americano e Caribenho (FPLyC)". Azusa - Revista de Estudos Pentecostais IV (2013), pp. 9-22.

${ }^{42}$ KNITTER, P. No Other Name? A Critical Survey of Christian Attitudes toward the World Religions. New York: Orbis Books, 1985, p. 222. Ver também: KNITTER, P. “A transformação da missão no paradigma pluralista”. Concilium 319-323 (2007), pp. 99-109; KNITTER, P. Introducing theologies of religions. New York: Orbis Books, 2002. 
teoentrismo, que busca fazer orbitar sobre a ideia de Deus todas as religiões de forma descentralizada. Aqui, não uma religião ou Cristo, mas a ideia de Deus como base para sistemas religiosos autônomos e paralelos. Na mesma linha José Maria Vigil propõe que a missão, dentro do modelo pluralista, supere a referência confessional. Isto é, a missão cristã deveria ocupar-se ou coincidirse com a missão humana: promoção do amor, da justiça, da liberdade, do bem dos pobres. Precisa superar o corporativismo que defende a Igreja ou o cristianismo sem mais, por cima das Causas de que a Igreja é devedora. Nossas causas são as grandes causas da humanidade, causas e sonhos de todos os povos e de Deus também. Não seria o critério escatológico pelo qual Deus julgará os seres humanos (cf. Mt 25.31ss) um critério não confessional? $\mathrm{Na}$ verdade, Vigil defende que esse critério é não eclesiástico, nem mesmo religioso. ${ }^{43}$

O modelo inclusivista, por sua vez, reconhece uma ação universal do Espírito, mas entende que é possível (e é querido por Deus) que essa ação divina seja tematizada a partir de Jesus Cristo. Dessa forma, não fica restrito à perspectiva eclesiocêntrica e nem atinge a teocêntrica. Assume uma postura cristocêntrica animada, relevantemente, em cada contexto pelo Espírito, considerando que a vinda de Deus em Jesus na encarnação e na ressurreição, incluiu toda a humanidade. Ser cristocêntrico e inclusivista aqui, não é simplesmente afirmar a verdade do cristianismo acima das demais religiões, mas partir da condição humana como a base que nos une como irmãos e irmãs. Para os cristãos, essa base humanizadora revelou-se na pessoa de Jesus. Esse modelo defende que "o anúncio explícito da fé faz crescer a chance salvífica e também a responsabilidade pessoal”. E continua França Miranda: “Além disso, considera-se hoje a missão tarefa dirigida não só a indivíduos, mas, sobretudo, aos povos e às culturas" ${ }^{\prime 4}$.

Essas posturas - de exclusivismo-eclesiocêntrica; inclusivismocristocêntrica e pluralismo-teocêntrica - reconhecem o pluralismo religioso como um grande desafio a ser encarado por qualquer teologia que se quer relevante hoje, cada uma propondo um percurso distinto. No entanto, o problema é que, como afirmou Wesley Ariarajah, "a missiologia continua a ser

\footnotetext{
${ }^{43}$ VIGIL, Teologia do pluralismo religioso, p. $337 \mathrm{~s}$.

${ }^{44}$ MIRANDA, O cristianismo em face das religiões, p. 30. Cf. RAHNER, K. "Mission und implizite Christlichkeit". In: Sacramentum Mundi III (1969), Freiburg, pp. 547-551; RAHNER, K. "Änonymes Christentum und Missionsauftrag der Kirche". Schriften zur Theologie IX (1970), Einsiedeln, pp. 498-515.
} 
um dos campos menos desenvolvidos da Teologia Cristã, porque nunca houve a coragem de pensá-la de maneira nova" ${ }^{45}$. Talvez aqui esteja o maior desafio, romper com antigas posturas e construir caminhos de unidade.

Christine Lienemann-Perrin propõe, então, uma teologia da missão que reconheça a pluralidade, que tenha parâmetros definidos a partir do amor e da não-violência, e, que se construa a partir do encontro e da interação. Em suas palavras:

Numa ótica empírica, será que a missão cristã ainda tem futuro no século XXI? Com certeza, em se considerando a dinâmica difusão do cristianismo em muitas partes do mundo. Não há dúvida de que a missão é realizada como obra da Igreja; a questão é como ela é encaminhada e referenciada em seu fundamento. Será que as grandes Igrejas se sujeitarão a seus bloqueios de missão, deixando o campo de missão entregue a forças preponderantemente reacionárias e fundamentalistas, para depois se queixar do despautério da missão? Ou será que elas próprias desenvolverão alternativas dignas de crédito, voltando a apresentar a transmissão da fé como sinal necessário da Igreja? A simultaneidade de demandas não simultâneas de missão proíbe a estipulação de regras detalhadas para a futura missão "nos seis continentes". Entretanto, todas as experiências feitas até aqui na história da missão necessariamente ditam um princípio que precisa vigorar independentemente do contexto e da situação: a renúncia à violência, coação, pressão e doutrinação para fins de difusão da fé. Isto constitui, por assim dizer, o duplo mandamento do amor para a missão, no qual estão compreendidos todos os demais requisitos. ${ }^{46}$

Para o cristianismo esse "duplo mandamento do amor" foi encarnado na pessoa de Jesus, sua referência máxima, e por isso específica e única. Assim, nossa proposta cristã de encontro religioso com o outro, parte da vida exemplar de Jesus de Nazaré como revelação de Deus para o mundo. A tarefa missionária cristã consistiria em inculturar a fé cristã nos diferentes contextos (povos e culturas), a partir do respeito e da solidariedade universal da humanidade, uma vez que os cristãos se sentem chamados a partilhar de sua fé e esperança. Mas não quer dizer que antes dos missionários a salvação de Jesus não lhes podia alcançar. Paulo declara que Deus não se deixou ficar sem testemunho

${ }^{45}$ ARIARAJAH, W. Repensando a missão para os nossos dias. São Bernardo do Campo: Editeo, 2011, p. 60.

${ }^{46}$ LIENEMANN-PERRIN, Missão e diálogo inter-religioso, p. 161. 
de si mesmo entre os povos (Romanos 1.14-15; Atos 14.17). Antes, porém, afirma-se que essa revelação se dá de modo pleno em Jesus. Por isso seria preciso conhecê-Lo, enquanto vida, obra e ensino. Na perspectiva cristã não se dá por certo que todos estejam captando adequadamente a revelação de Deus. Pensar a mediação de Jesus nesse processo torna-se necessário. Esse é o tema do próximo tópico.

\subsection{Jesus como mediador da revelação de Deus ${ }^{47}$}

O cristianismo advoga que a revelação de Deus não acontece indistintamente. Da mesma forma, a revelação não é captada igualmente por todos. Muitas culturas desenvolveram suas respostas às provocações de Deus e muitas vezes foram ineficazes. As religiões podem ser expressão do egoísmo e da limitação humana. Nem por isso elas estariam descartadas ou seriam consideradas errôneas. Já houve períodos em que teólogos cristãos (e igrejas) atribuíam às outras religiões um caráter demoníaco - especialmente às religiões indígenas e africanas. Infelizmente, ainda há igrejas que pensam assim. Assumimos, ao contrário, que as religiões não-cristãs são legítimas, no sentido de ser o meio de que os indivíduos dispõem para responder a Deus. Contudo, a pergunta é: constituem as demais religiões alternativas possíveis ao cristianismo? A resposta passa por um dado concreto: nelas também ocorrem eventos salvíficos porque a ação do Espírito pode ser captada por caminhos que desconhecemos. De qualquer forma, para o cristianismo, a salvação foi no modo de Jesus, isto é, é Cristo quem salva. Não haveria outro mediador. ${ }^{48} \mathrm{E}$ isso não precisa ser um empecilho para o diálogo inter-religioso, pois trata-se de uma confissão de fé, de um posicionamento firme que os cristãos sustentam ao entrar em diálogo com outras confissões.

Afirmar ser Jesus Cristo a verdade última de Deus não significa que tenhamos já a compreensão e a expressão definitiva dessa mesma verdade. Nosso conhecimento é sempre fragmentário e imperfeito, contextualizado e limitado. Portanto suas expressões devem estar abertas a ulteriores correções e aperfeiçoamentos. Schillebeeckx chega a admitir aspectos verda-

${ }^{47}$ Este tópico foi adaptado de uma reflexão anterior. Ver, OLIVEIRA, David Mesquiati. "Salvação, acolhida do ser humano e a obra do Espírito Santo". Atualidade Teológica 43 (2013), pp. 39-69. Aqui, p. 48-49.

${ }^{48}$ MIRANDA, M. F. A salvação de Jesus Cristo: a doutrina da graça. São Paulo: Loyola, 2004, p. 213s. 
deiros, bons e belos de experiências com Deus que não conseguem encontrar sua expressão na experiência religiosa transmitida pelo cristianismo. ${ }^{49}$

Nesse sentido, Claude Geffré acentua a limitação do cristianismo como religião histórica:

Quando falamos em termos de singularidade ou de unicidade, é preciso tentar refletir no que pode ser uma unicidade relativa em relação a uma unicidade de excelência ou de integração. E é aí que é urgente repensar de uma forma nova a noção de cumprimento. É verdade que Cristo cumpriu todas as coisas, mas eu não diria que o cristianismo como religião histórica cumpriu todas as outras religiões..$^{50}$

O encontro entre cristãos e adeptos de outras religiões, então, não poderia ser de mútua condenação. Tampouco seria o caso de validação acrítica. Haveria um critério capaz de discernir nas expressões religiosas o que corresponde à ação de Deus na história. Esse critério para o cristão é Jesus Cristo (Deus na história produzindo vida). Isso as outras religiões não teriam. No modelo cristão, Jesus esteve guiado pela atitude fundamental de obediência ao Pai e de entrega aos seres humanos. França Miranda afirma que foi essa atitude fundamental que trouxe salvação a Jesus, pois, motivado por isso, o Pai o ressuscitou ${ }^{51}$. Em linguagem teológica, o Espírito levaria cada ser humano a assumir a vida de Jesus para que chegue à salvação definitiva. Toda a ação do Espírito é de fazer cada pessoa “outros Cristos”, “outros Filhos” (Romanos 8.14-16; Gálatas 4.6)

Contudo, a fé cristã reafirma que outros reveladores são sempre penúltimos, pois, devido à limitação (estruturalmente) e à pecaminosidade (historicamente) inerentes à condição humana, podem estar a absolutizar não a realidade última, mas projeções de seus próprios interesses. O que também vale para as figuras bíblicas que precederam Jesus Cristo, que nem por isso deixaram de atuar como manifestações e mediações da salvação de Jesus Cristo, já que a fé cristã não reconhece outra. ${ }^{53}$

\footnotetext{
${ }^{49}$ MIRANDA, $O$ cristianismo em face das religiões, p. 70.

${ }^{50}$ GEFFRÉ, C. Crer e interpretar: a virada hermenêutica da teologia. Petrópolis: Vozes, 2001, p. 169.

${ }^{51}$ MIRANDA, A salvação de Jesus Cristo, p. 148.

${ }^{52}$ MIRANDA, A salvação de Jesus Cristo, p. 171 e 210.

${ }^{53}$ MIRANDA, O cristianismo em face das religiões, p. 67.
} 
Para a confissão cristã, Jesus Cristo é a revelação máxima de Deus, suficiente, definitiva, única e ao mesmo tempo, multiforme. Esse reconhecimento da própria experiência de fé como uma confissão existencial, verdadeira e fundamental, não poderia ser absolutizada para todos os demais. Se juntamente com o respeito à diferença se fizer acompanhar a disposição para honrar a singularidade e a originalidade das diferentes tradições religiosas, o cristianismo estaria dando sua contribuição para a boa convivência entre os seres humanos, independente do credo. Como afirmou Ariarajah: "Por mais verdadeira que seja nossa experiência, por mais convencidos que estejamos de uma confissão de fé, temos que situá-la como confissão de fé e não como uma verdade em sentido absoluto". ${ }^{54}$ Além disso, a salvação de Jesus Cristo não é a salvação do cristianismo nem a salvação de nenhuma religião. A salvação estaria em Jesus enquanto atitude fundante de amor fraterno. ${ }^{55}$ Trata-se de uma capacidade humanizadora. Quanto mais próxima do Deus revelado em Jesus Cristo os seres humanos pudessem chegar em sua imitação da atitude crística, mas humanos seriam. Irmanados, estariam desafiados a aprender a aceitarem-se mutuamente, apesar das diferenças. Além disso, o fato de se pensar em Cristo como único, enquanto Mediador, não deveria ser transposto para as Igrejas Cristãs, pois a Ecclesia Christi (escatológica e universal) é uma realidade de grandeza teológica maior que as Igrejas históricas.

\subsection{Dialogais e missionários: desafios atuais}

Juan José Tamayo indica que o desafio que se apresenta é o de viver um "cristianismo universal culturalmente policêntrico" "56. Essa nova configuração da fé cristã está deixando de ser cêntrica para ser peregrina, rompendo com o dualismo igreja mãe e igreja filha, igreja enviadora e igreja que recebe missionário. Infelizmente, o respeito ao outro e à diversidade nem sempre se plasmaram na história do cristianismo, embora sejam valores caros à fé cristã. Voltando ao tema da salvação, tomemos a reflexão de Ratzinger quando afirma que "a salvação não reside nas religiões como tais, mas depende delas na medida em que as religiões conduzem o homem ao bem único e à procura

\footnotetext{
${ }^{54}$ ARIARAJAH, W. La Bíblia y las gentes de otras religiones. Santander: Sal Terrae, 1998, p. 114.

${ }^{55}$ OLIVEIRA, "Salvação, acolhida do ser humano e a obra do Espírito Santo", p. 49.

${ }^{56}$ TAMAYO, J. J. Nuevo paradigma teológico. Madrid: Trotta, 2004, p. 49. (Grifos no original).
} 
de Deus, da verdade e do amor. Por isso, a questão da salvação contém sempre um elemento de crítica da religião" "57. A salvação ocupa-se da unidade de Deus e do ser humano, e as religiões e as culturas não são capazes de autossalvação (autocrítica), devendo, portanto, abrir-se para encontrar Deus. Nenhuma cultura exaure as potencialidades do ser humano, devendo este abrir-se para Deus. ${ }^{58} \mathrm{O}$ enclausuramento das culturas e das religiões nega aos seus integrantes ao que transcende.

Procurar ultrapassar a imanência é uma forma de autocrítica da cultura e do pensamento próprio. Nesse sentido, procurar Deus é ser inserido pela fé na dinâmica da auto superação ${ }^{59}$. Sendo Jesus mediador por excelência, ele seria a verdade última de Deus e o sentido último da existência humana - esta é a base da fé cristã. Nesse sentido, afirma Ratzinger: "A fé em Jesus Cristo é, portanto, em sua própria essência, um contínuo abrir-se, é a irrupção de Deus no mundo dos homens e a resposta destes como partida ao encontro de Deus, que simultaneamente leva os homens a encontraremse entre si" $" 60$.

A cultura não vive somente da herança do passado, mas também dos desafios do futuro. Castro Quiroga afirma que, ao criticar sua própria cultura, abrindo espaço à novidade e construindo um futuro diverso, as culturas manifestam seu caráter humano: "as culturas não crescem por autofecundação senão por interfecundação, abrindo-se umas às outras em um recíproco influxo" ${ }^{1}$. A missão não poderia ser compreendida como imposição ou dominação; antes como diálogo e mútuo enriquecimento. Daí a opção pela enculturação, para que essa fé nasça a partir de dentro de cada cultura e dialogue com as diferentes religiões na profundidade de sua cosmovisão.

Também, não se pode confundir evangelização com cristianização do mundo. Entendemos que a evangelização é "a proclamação da salvação em Cristo às pessoas que não creem nele, chamando-as ao arrependimento e à conversão, anunciando o perdão do pecado e convidando-as a tornarem-

\footnotetext{
${ }^{57}$ RATZINGER, J. "Fé, verdade e cultura: reflexões a propósito da encíclica Fides et Ratio II". Communio 6 (1999), pp. 557-568. Aqui p. 560.

${ }^{58}$ MIRANDA, “As religiões na única economia salvífica”, p. 25.

${ }^{59}$ RATZINGER, "Fé, verdade e cultura I”, p. 471.

${ }^{60}$ RATZINGER, "Fé, verdade e cultura I", p. 471.

${ }^{61}$ CASTRO QUIROGA, L. A. El gusto por la misión: manual de misionología para seminarios. Bogotá: Celam, 1994, p. 312, 313.
} 
se membros vivos da comunidade terrena de Cristo e a começar uma nova vida de serviço aos outros no poder do Espírito Santo"62. Esse é um convite. Permanece aberto. É uma proposta de vida. As pessoas podem aceitá-lo ou não. Já a cristianização é um projeto de conquista que reveste alguns programas missionários.

A evangelização é, também, "parte integrante da pedagogia divina de respeito à liberdade humana, na relação, cheia de mistério e de misericórdia, de Deus com a humanidade de todos os tempos"63. Partilhar a fé com o outro não é colonizá-lo, nem necessariamente colocar-se em superioridade na relação. A autorrevelação de Deus como Aquele que ama o mundo, um Deus-para as/pelas-pessoas fundamenta uma tarefa missionária voltada para atender às profundas necessidades e exigências da vida humana. Portanto, não se trata de um modelo cristianizador, de mão única, impositivo, colonizador, mas promotor de vida e dignidade em uma lógica dialogal. ${ }^{64}$

Necessitamos de um modelo missionário que trabalhe com a reciprocidade ${ }^{65}$, que avance da perspectiva moderna que trata o outro como objeto para considerá-lo sujeito da sua própria história. Mas não só ter o outro como sujeito, mas, voluntariamente, abrir-se para ser tocado pelo outro (ser disciplinado e enriquecido pela perspectiva e sabedoria do outro). Reconhecer e assumir a vulnerabilidade como característica definidora ${ }^{66}$. Não impor nossa verdade, mas fazer menção da Revelação de Deus que recebemos como cristãos, e desafiar cada cultura, a essa "abertura". França Miranda expõe:

No momento em que o cristianismo aceita o diálogo com outras religiões, deve procurar vê-las a partir de seus horizontes respectivos. Esse procedimento árduo e exigente, que de modo algum questiona a própria identidade cristã, lhe oferece outros horizontes para olhar a si

\footnotetext{
${ }^{62}$ BOSCH, Missão transformadora, p. 28.

${ }^{63}$ AZEVEDO, M. C. "Contexto geral do desafio da inculturação". In: ANJOS, M. F. Teologia da inculturação e inculturação da teologia. Petrópolis: Vozes, 1995, pp. 13-27. Aqui, p. 16. ${ }^{64} \mathrm{BOSCH}$, Missão transformadora, p. 335.

${ }^{65}$ Apresentamos mais detalhadamente essa proposta em: OLIVEIRA, David Mesquiati. Diálogo e missão nos Andes: um estudo de teologia da missão latino-americana. São Paulo: Garimpo Acadêmico, 2016.

${ }^{66}$ OLIVEIRA, David Mesquiati. Missão, cultura e transformação: desafios para a prática missionária comunicativa. São Leopoldo: Sinodal; Quito: CLAI, 2011, pp. 70-75, 145-148.
} 
próprio, capacitando-o a reinterpretar a verdade que é Jesus Cristo com outras linguagens e estruturas mentais. Fundamental aqui é reconhecer que esses novos horizontes e essas novas expressões religiosas não são a priori neutras ou hostis à fé cristã. Pois estão também prenhes dos elementos crísticos. ${ }^{67}$

Além disso, a inculturação permanece um processo tentativo e continuado, em que as Igrejas serão ainda surpreendidas, ao descobrir mistérios da fé, aos quais estavam antes, impossibilitadas culturalmente. Para isso, precisam manter-se una e não fragmentadas autonomamente. Em nome do diálogo e para serem aceitas em um mundo plural e até relativista, não caberiam, do ponto de vista da teologia, igrejas e comunidades provincializadas. É fundamental que se fomente o contato vital como igreja em sentido mais amplo. Na metáfora paulina de Corpo de Cristo pode-se depreender que, só é corpo, porque o que as partes que o constituem, estão intimamente unidas e inter-relacionados. Trata-se de uma unidade orgânica. David Bosch afirmou:

Enquanto agimos localmente, temos que pensar globalmente, em termos da una sancta, combinado à micro e às macroperspectivas. É verdade que a Igreja existe primordialmente em Igrejas particulares (LG 23), mas também é verdade que é em virtude da catolicidade da Igreja (cf. LG 13) que as Igrejas particulares existem - e isso vale não apenas para a Igreja Católica Romana como estrutura eclesiástica internacional, mas para todas aquelas comunidades que se denominam "cristãs". Se a Igreja é o Corpo de Cristo, ela só pode ser uma. ${ }^{68}$

Essa Igreja cristã una não é, e não poderia ser, uma entidade supracultural idealista. É, antes, uma comunidade hermenêutica universal. Nela, os cristãos de todo o mundo, embora com teologias locais, checam reciprocamente seus vieses culturais ${ }^{69}$. A partir do que entendem ser a proposta do Evangelho, fazem importantes contribuições para o tesouro comum da humanidade. ${ }^{70}$ Aqui fica evidente que uma atitude positiva

\footnotetext{
${ }^{67}$ MIRANDA, “As religiões na única economia salvífica”, p. 23.

${ }^{68} \mathrm{BOSCH}$, Missão transformadora, p. 546.

${ }^{69}$ HIEBERT, P. apud BOSCH, Missão transformadora, p. 546.

${ }^{70}$ KIRK, J. A. O que é missão? Teologia bíblica de missão. Londrina: Descoberta, 2006, p. 130 e 131 .
} 
do cristianismo em relação às ouras religiões depende, de algum modo, de quão positivamente são vistas as diferenças internas no próprio cristianismo. Assim, sem uma mentalidade ecumênica amadurecida e aberta para novas elaborações, não se avança no diálogo com as pessoas de nosso tempo.

\section{Considerações finais}

Vimos que uma nova mentalidade dialogal está se processando, tanto em seio católico como no protestante, inclusive no pentecostal. É um processo lento que ainda levará muito tempo. Estão em questão tradições assentadas e identidades forjadas durante séculos. Isso não quer dizer que nunca se dialogou ou que nunca houve respeito à diferença. Estamos enfatizando que, estamos agora em um tempo de maior percepção da pluralidade e de uma decisão de enfrentá-la positivamente.

Os cristãos valorizam a revelação do Evangelho que receberam de Jesus. Mas sabem que não existe Evangelho em estado puro, pois está sempre inculturado, e as culturas, todas elas, têm elementos para conversão. Thomas Groome descreve a inculturação em termos de "encontro dialético entre fé e cultura". Na inculturação "a cultura é afirmada, questionada e transformada em prol do reino de Deus", e, da mesma forma, "a fé cristã é igualmente afirmada, questionada e enriquecida por essa singular instância de sua realização"71. O parâmetro aqui é a categoria de "Reino de Deus", que desafia a todos, inclusive a cultura do missionário. O "reino" é um símbolo compreensivo das intenções de Deus para com toda a criação, que podem ser expressas como paz e justiça, amor e liberdade, plenitude de vida para toda humanidade. Dessa forma, encontrar-se com o outro deve ser pautado em atitudes mais positivas e em confiança. Torres Queiruga acentua que a atitude esperada é de encontro, respeito e reciprocidade.

O que uma religião tencione oferecer de novo a outras não pode nunca ter por objetivo suprimi-las, mas unicamente ajudá-las. Como São Paulo esclareceu, na relação do Evangelho com o judaísmo, não se trata de uma substituição, mas, antes, de um "enxerto". Dessa maneira,

${ }^{71}$ GROOME, T. "Inculturação: como proceder num contexto pastoral". Concilium 251 (1994), pp. 134-149. Aqui, p. 136. 
quem recebe a outros, incorporando livremente aquilo que neles ache convincente, não renega sua própria tradição, mas sim a renova e enriquece. $^{72}$

Com isso, na missão, respeitar-se-á não só as diferentes culturas, mas também as diferentes religiões, abertamente. Sendo um mundo plural, a missão e o diálogo inter-religioso deverão andar sempre juntos. Vigil acentua: "o pluralismo afirma a relatividade das formas religiosas, não o relativismo diante das religiões [...] O pluralismo reconhece a relatividade de algumas coisas antes indevidamente tidas por absolutas, porém não cai no relativismo". E continua: "Não faz parte do pluralismo religioso a afirmação de que a variedade formal das religiões é puramente fenomênica e não contém de alguma maneira verdade real (noumênica) no que afirma sobre Deus [...] a verdade das religiões é real [ainda que inadequado, precário]". ${ }^{73} \mathrm{O}$ exercício para discernir essas verdades em um mundo plural é permanente. Exige disciplina, humildade e serviço ao outro. Esse é o eixo da missão para nosso tempo: serviço em reciprocidade, tratando o outro como igual, membros do povo de Deus que se manifesta em diferentes famílias.

O encontro com o outro na prática missionária deveria pautar-se pelo respeito à diferença, pela provisoriedade das sistematizações, pela superação de conflitos e por uma atitude de escuta, que possibilitasse a criação de pontes com pessoas de outras religiões, visando contribuir para a vida em seu sentido amplo. Todas as religiões, incluindo o cristianismo, são convidadas a perceberem em seus caminhos e projetos de ação o chamado para a unidade, para a construção da paz e para a fraternidade. Cada um e cada uma em suas respectivas veredas seriam irmãos e irmãs de fé em busca de maturidade espiritual e compromisso com a vida. Sendo a fé cristã uma fé missionária, a dimensão do anúncio estará sempre presente. E é bom que o faça, pois assim, estará compartilhando com o mundo a riqueza de seus tesouros. Ao mesmo tempo, deverá reconhecer que existem mais tesouros em outros grupos e vivências, que também querem ser reconhecidos, respeitados e compartilhados. Juntos, estes tesouros enriquecem toda a humanidade.

72 TORRES QUEIRUGA, Andrés. A teologia depois do Vaticano II: diagnóstico e propostas. São Paulo: Paulinas, 2015, p. 171.

${ }^{73}$ VIGIL, Teologia do pluralismo religioso, p. 90. 
Assim, o pluralismo, o diálogo inter-religioso e a missão podem ajudar a dar maior visibilidade a toda essa riqueza, que, intercambiada, criticada e apropriada em diferentes mesas de encontro da raça humana, promovam o Bem Comum e a vinculação dos seres humanos uns com os outros. Dessa forma, as religiões poderiam desempenhar um papel humanizador, em que o propósito não seria produzir crente, senão gente, pessoas plenas, realizadas, interconectadas.

\section{Referências bibliográficas}

AMALADOSS, M. Pela estrada da vida: prática do diálogo inter-religioso. São Paulo: Paulinas, 1995.

ARIARAJAH, W. La Bíblia y las gentes de otras religiones. Santander: Sal Terrae, 1998.

ARIARAJAH, W. Repensando a missão para os nossos dias. São Bernardo do Campo: Editeo, 2011.

AZEVEDO, M. C. "Contexto geral do desafio da inculturação". In: ANJOS, M. F. Teologia da inculturação e inculturação da teologia. Petrópolis: Vozes, 1995, pp. 13-27.

BALTHASAR, H. U. Epilogue. San Francisco: Ignatius, 1995.

BATISTA, Israel (Org.). Desafios missionários da cooperação: diálogo entre as Igrejas da Europa e da América Latina. São Leopoldo: Sinodal; Quito: CLAI, 2007.

BEEK, Hubert van. "O Fórum Cristão Mundial e a busca pela unidade cristã". In: OLIVEIRA, David Mesquiati (Org.). Pentecostalismos e unidade. São Paulo: Fonte Editorial; FPLC, 2015, pp. 13-26.

BOSCH, D. J. Missão transformadora: mudanças de paradigma da teologia da missão. 2. ed. São Leopoldo: Sinodal, 2007.

BÜRKLE, Heinz. “Teologia das religiões”. In: LACOSTE, Jean-Yves (Dir.). Dicionário crítico de teologia. São Paulo: Paulinas; Loyola, 2004, pp. 1514-1518.

CASTRO QUIROGA, L. A. El gusto por la misión: manual de misionología para seminarios. Bogotá: Celam, 1994. 
COMISSÃO TEOLÓGICA INTERNACIONAL. O cristianismo e as religiões. São Paulo: Loyola, 1997.

D'ACOSTA, Gavin. La trinidad y el diálogo interreligioso. Salamanca: Secretaria Trinitario, 2006.

GEFFRÉ, C. Crer e interpretar: a virada hermenêutica da teologia. Petrópolis: Vozes, 2001.

GROOME, T. "Inculturação: como proceder num contexto pastoral". Concilium 251 (1994), pp. 134-149.

HELFENSTEIN, Pius F. Grundlagen des interreligiösen Dialogs. Theologische Rechtfertigungsversuche in der ökumenischen Bewegung und die Verbindung des trinitarischen Denkes mit dem pluralistischen Ansatz. Frankfurt am Main, 1998.

KIRK, J. A. O que é missão? Teologia bíblica de missão. Londrina: Descoberta, 2006.

KNITTER, P. "A transformação da missão no paradigma pluralista". Concilium 319-323 (2007), pp. 99-109.

KNITTER, P. Introducing theologies of religions. New York: Orbis Books, 2002.

KNITTER, P. No Other Name? A Critical Survey of Christian Attitudes toward the World Religions. New York: Orbis Books, 1985.

LIBANIO, J. B. "Questões pendentes do Concílio Vaticano II”. In: BRIGHENTI, Agenor; ARROYO, Francisco Merlos (Orgs.). O Concílio Vaticano II: batalha perdida ou esperança renovada? São Paulo: Paulinas, 2015, pp. 329-351.

LIENEMANN-PERRIN, Christine. Missão e diálogo inter-religioso. São Leopoldo: Sinodal, EST, CEBI, 2005.

LONGUINI NETO, Luiz. O novo rosto da missão: Os movimentos ecumênicos e evangelical no protestantismo latino-americano. Viçosa: Ultimato, 2002.

MATTOS, P. A. "Para uma teologia ecumênica das religiões no Brasil". Tempo e Presença 25, n. 332 (2003), pp. 12-15. 
MIRANDA, M. F. “As religiões na única economia salvífica”. Atualidade Teológica 10 (2012), pp. 9-26.

MIRANDA, M. F. A igreja numa sociedade fragmentada. São Paulo: Loyola, 2006.

MIRANDA, M. F. A salvação de Jesus Cristo: a doutrina da graça. São Paulo: Loyola, 2004.

MIRANDA, M. F. O cristianismo em face das religiões. São Paulo: Loyola, 1998.

MIRANDA, M. F. Um homem perplexo. O cristão na atual sociedade. 3. ed. São Paulo: Loyola, 1996.

OLIVEIRA, David Mesquiati. Diálogo e missão nos Andes: um estudo de teologia da missão latino-americana. São Paulo: Garimpo Acadêmico, 2016.

OLIVEIRA, David Mesquiati. Missão, cultura e transformação: desafios para a prática missionária comunicativa. São Leopoldo: Sinodal; Quito: CLAI, 2011.

OLIVEIRA, David Mesquiati. "Salvação, acolhida do ser humano e a obra do Espírito Santo”. Atualidade Teológica 43 (2013), pp. 39-69.

OLIVEIRA, David Mesquiati. "Os pentecostais e a mesa de debate: o caso do Fórum Pentecostal Latino-americano e Caribenho (FPLyC)". Azusa Revista de Estudos Pentecostais IV, pp. 9-22, 2013.

PANIKKAR, R. The Intrareligious Dialogue. New York: Paulist, 1978.

PAPA FRANCISCO. Palavras do Papa Francisco no Brasil. São Paulo: Paulinas, 2013.

PAPA FRANCISCO. Comunicação a Serviço de uma autêntica cultura do encontro. São Paulo: Paulinas; Paulus, 2014. (48 Dia Mundial das Comunicações Sociais).

PAPA FRANCISCO. Evangelii Gaudium: Exortação apostólica do Sumo Pontífice. São Paulo: Loyola; Paulus, 2013.

RACE, Alan. Christians and Religious Pluralism: Patterns in the Christian Theology of Religious. Londres: SCM, 1983.

RAHNER, K. "Änonymes Christentum und Missionsauftrag der Kirche". Schriften zur Theologie IX (1970), pp. 498-515. 
RAHNER, K. "Mission und implizite Christlichkeit". Sacramentum Mundi III (1969), Freiburg, pp. 547-551.

RATZINGER, J. "Fé, verdade e cultura: reflexões a propósito da encíclica Fides et Ratio I". Communio 5 (1999), p. 464-472.

RATZINGER, J. "Fé, verdade e cultura: reflexões a propósito da encíclica Fides et Ratio II". Communio 6 (1999), pp. 557-568.

SANDERS, J. (Ed.). E aqueles que nunca ouviram? Três pontos de vista sobre o destino dos não-evangelizados. Arapongas: Aleluia, 1999.

SANTOS, Lyndon de Araújo. "Diálogo inter-religioso". In: BORTOLLETO FILHO, Fernando (Org.). Dicionário brasileiro de teologia. São Paulo: ASTE, 2008.

SASS, W. "O Deus trinitário está presente antes da chegada do missionário". Estudos Teológicos 2 (2004), pp. 73-81.

SCHWÖBEL, Christoph. "Encontro inter-religioso e experiência fragmentária de Deus". Concílium 289 (2001), pp. 111-125.

SWIDLER, L. Cristãos e não-cristãos em diálogo. São Paulo: Paulinas, 1988.

TAMAYO, Juan José. Nuevo paradigma teológico. Madrid: Trotta, 2004.

TEIXEIRA, F. Indagações em torno da teologia do pluralismo religioso. Post scriptum (reflexões de 2005), 2012, pp. 1-4. Disponível em: $<\mathrm{http}$ ://servicioskoinonia.org/relat/357.htm>. Acesso em 11 de fevereiro de 2015.

TEIXEIRA, Faustino. "Caminhos do diálogo inter-religioso a partir do Vaticano II". In: BRIGHENTI, Agenor; ARROYO, Francisco Merlos (Orgs.). O Concílio Vaticano II: batalha perdida ou esperança renovada? São Paulo: Paulinas, 2015, pp. 244-261.

TORRES QUEIRUGA, A. "El diálogo de las religiones en el mundo actual". In: GOMIS, J. (Org.). El Vaticano III. Cómo lo imaginan 17 cristianos. Barcelona: Herder; El Ciervo, 2001, pp. 67-84.

TORRES QUEIRUGA, A. A teologia depois do Vaticano II: diagnóstico e propostas. São Paulo: Paulinas, 2015. 
VIGIL, José Maria. Teologia do pluralismo religioso: para uma releitura pluralista do cristianismo. São Paulo: Paulus, 2006.

David Mesquiati de Oliveira

Pós-doutorando em Teologia pelo PPGT da Pontifícia Universidade Católica do Rio de Janeiro Doutor em Teologia pela Pontifícia Universidade Católica do Rio de Janeiro Docente do PPGCR da Faculdade Unida de Vitória Vitória / ES - Brasil E-mail: david@faculdadeunida.com.br

Recebido em: $15 / 11 / 15$

Aprovado em: 27/04/16 